\title{
EFEKTIVITAS PROGRAM REHABILITASI KORBAN PERDAGANGAN ORANG
}

\section{EFFECTIVENESS OF REHABILITATION PROGRAM OF HUMAN TRAFFICKING VICTIM}

\author{
Putri Nabila1*, M. Rijal Amirulloh², Yana Fajar Fitri Yana Basori ${ }^{3}$ \\ 1,2,3Program Studi Administrasi Publik, Fakultas Ilmu Administrasi dan Humaniora, \\ Universitas Muhammadiyah Sukabumi, Jl. R. Syamsudin, SH No. 50, Cikole, Kota Sukabumi \\ 43113
}

*Korespondensi: Putri Nabila. Email: putribya@gmail.com

(Diterima: 18-08-2020; Ditelaah: 22-08-2020; Disetujui: 25-08-2020)

\begin{abstract}
The human trafficking in Sukabumi City during 2017-2019 had increased. The increase of the victim numbers was caused by the lack of information about human trafficking mode and danger and the consumptive behavior coming into human trafficking victim. The human trafficking victims were necessarily rehabilitated. During 2017-2019, the Government of Sukabumi City had implemented the rehabilitation of human trafficking victims. The purpose of this research is to describe the effectiveness of rehabilitation program of human trafficking victim in Sukabumi City. This research uses five dimensions of program effectiveness including the program comprehension, target accuracy, time accuracy, goal attainment and presence of real change. The method of this research is a qualitative approach combined by a descriptive research to describe the actual phenomena of field events. The data collection uses techniques of interview, observation and documentation related to this research. The data of this research are qualitatively described. This research concludes that the effectiveness of rehabilitation program of human trafficking victim in Sukabumi City is generally perceived as good, although there are several obstacles that appear in implementation such as the lack of facilities, choice of method, budget allocation and socialization of human trafficking victim rehabilitation.
\end{abstract}

Key words: Program Effectiveness, Human Trafficking, Rehabilitation Program, Victim Rehabilitation.

\begin{abstract}
ABSTRAK
Perdagangan orang di Kota Sukabumi selama tahun 2017-2019 mengalami peningkatan. Peningkatan jumlah korban tersebut disebabkan oleh kurangnya informasi tentang modus dan bahaya perdagangan orang dan juga perilaku konsumtif yang menjerumuskan masuk ke dalam korban perdagangan. Korban perdagangan orang perlu direhabilitasi. Selama tahun 2017-2019, Pemerintah Kota Sukabumi melakukan rehabilitasi korban perdagangan orang. Tujuan penelitian ini adalah untuk mengetahui efektivitas program rehabilitasi korban perdagangan orang di Kota Sukabumi. Penelitian ini menggunakan lima dimensi efektivitas program yang meliputi pemahaman program, ketepatan sasaran, ketepatan waktu, tercapainya tujuan dan adanya perubahan nyata. Metode yang digunakan dalam penelitian ini adalah pendekatan kualitatif yang dipadukan dengan penelitian deskriptif untuk menggambarkan fenomena sebenarnya dari kejadian-kejadian di lapangan. Pengumpulan data penelitian menggunakan teknik wawancara, observasi dan dokumentasi yang terkait dengan penelitian. Data penelitian dideskripsikan secara kualitatif. Penelitian ini menyimpulkan bahwa efektivitas program rehabilitasi korban perdagangan orang di Kota Sukabumi secara umum dinilai baik, meskipun terdapat beberapa hambatan yang terjadi pada pelaksanaannya seperti kurangnya fasilitas sarana dan prasarana, pilihan metode, alokasi anggaran dan sosialisasi rehabilitasi korban perdagangan orang.
\end{abstract}

Kata kunci: Efektivitas Program, Perdagangan Orang, Program Rehabilitasi, Rehabilitasi Korban.

Nabila, Putri; Amirulloh, M. Rijal \& Basori, Yana Fajar Fitri Yana. (2021). Efektivitas Program Rehabilitasi Korban Perdagangan Orang. Jurnal GOVERNANSI, 7 (1): 59-68. 


\section{PENDAHULUAN}

Perdagangan orang di Indonesia merupakan masalah yang serius dan besar karena terjadi peningkatan jumlah korban dari tahun ke tahun. Perdagangan orang (human trafficking) memiliki dampak yang besar bagi korban, yaitu trauma karena kejadian yang dialami sangat membuatnya takut, gangguan kesehatan karena keadaan kesehatan korban sangat tidak diperhatikan oleh pelaku penjualan, dan juga dapat menyebabkan cacat fisik apabila korban mengalami kekerasan. Hal tersebut menjadi perhatian pemerintah untuk mencegah terjadinya peningkatan korban perdagangan orang.

Perdagangan orang terjadi karena beberapa faktor seperti rendahnya tingkat pendidikan yang berpengaruh terhadap rendahnya tingkat ekonomi, kurangnya edukasi mengenai bahaya tindak kejahatan perdagangan orang, gaya hidup yang konsumtif dan juga meningkatnya kejahatan terorganisir sehingga memudahkan mendapatkan korban.

Menurut International Organization for Migration (IOM), selama tahun 20052018 di Indonesia tercatat sebanyak 6.651 korban perdagangan orang dengan $15 \%$ di antaranya merupakan anak-anak dan $85 \%$ wanita dewasa dan juga pria. Jumlah korban perdagangan orang di Indonesia tersebar di beberapa provinsi. Provinsi dengan jumlah korban perdagangan orang terbanyak adalah Nusa Tenggara Timur, Nusa Tenggara Barat, Jawa Timur, Jawa Tengah dan Jawa Barat (okezone.com, 2020).

Dalam upaya untuk merehabilitasi korban perdagangan orang, Pemerintah Kota Sukabumi menerbitkan Peraturan Daerah Nomor 6 Tahun 2016 tentang Penyelenggaraan Kesejahteraan Sosial. Dalam Perda tersebut diatur juga tentang program rehabilitasi terhadap korban perdagangan orang di Kota Sukabumi. Rehabilitasi merupakan program pilihan Pemerintah Kota Sukabumi untuk membantu pemulihan secara terpadu, baik fisik, psikis maupun sosial terhadap korban perdagangan orang. Dalam melaksanakan program rehabilitasi terhadap korban perdagangan orang, Dinas Sosial Kota Sukabumi telah melakukan rehabilitasi korban dalam tiga tahun terakhir (Tabel 1).

Tabel 1. Data Rehabilitasi Korban Perdagangan Orang di Kota Sukabumi

\begin{tabular}{ccc}
\hline No. & Tahun & Jumlah Rehabilitasi \\
\hline 1 & 2017 & 30 \\
\hline 2 & 2018 & 35 \\
\hline 3 & 2019 & 2 \\
\hline & Jumlah & 67 \\
\hline
\end{tabular}

Sumber: Dinas Sosial Kota Sukabumi (2019)

Data pada Tabel 1 di atas menunjukkan bahwa selama tahun 2017-2019 Dinas Sosial Kota Sukabumi telah merehabilitasi korban perdagangan orang sebanyak 67 orang. Meskipun demikian, perdagangan orang dalam tiga tahun terakhir terus terjadi di Kota Sukabumi (Tabel 2).

Tabel 2. Data Perdagangan Orang di Kota Sukabumi

\begin{tabular}{ccc}
\hline No. & Tahun & Jumlah Rehabilitasi \\
\hline 1 & 2017 & 46 \\
\hline 2 & 2018 & 50 \\
\hline 3 & 2019 & 4 \\
\hline & Jumlah & 100 \\
\hline
\end{tabular}

Sumber: Dinas Sosial Kota Sukabumi (2019)

Data pada Tabel 2 di atas menunjukkan bahwa di Kota Sukabumi terjadi peningkatan perdagangan orang selama tahun 2017-2018 dengan jumlah korban 46 orang menjadi 50 orang. Peningkatan jumlah korban tersebut disebabkan oleh kurangnya informasi tentang modus dan bahaya perdagangan orang dan juga perilaku konsumtif yang membuat mereka mampu masuk ke dalam korban perdagangan. Di Kota Sukabumi terdapat 100 orang korban perdagangan orang dalam jangka waktu tiga tahun terakhir. Sedangkan jumlah korban perdagangan orang yang direhabilitasi adalah sebanyak 67 orang.

Selain itu, dalam proses rehabilitasi tersebut tidak ada tindak lanjut dari Dinas Sosial Kota Sukabumi terhadap korban 
perdagangan saat setelah dilakukannya rehabilitasi. Sedangkan dalam Perda Kota Sukabumi Nomor 6 Tahun 2016 Pasal 19 diatur tentang bentuk rehabilitasi sosial berupa bimbingan lanjut. Ini berarti bahwa korban saat setelah selesai melaksanakan rehabilitasi harus ada pengawasan sebagai tindak lanjut dari proses rehabilitasi.

\section{MATERI DAN METODE}

\section{Teori/Konsep yang Relevan}

Badrudin (2013: 31) mendefinisikan efektif sebagai "kemampuan mengerjakan sesuatu dengan benar dan sesuai" dan "efektivitas berkaitan dengan tujuan karena semakin dekat organisasi kepada tujuannya, maka semakin efektif organisasi tersebut karena melaksanakan kegiatan sesuai rencana." Steers (1985: 87) mengartikan efektivitas sebagai "jangkauan usaha suatu program sebagai suatu sistem dengan sumber daya dan sarana tertentu untuk memenuhi tujuan dan sasarannya tanpa melumpuhkan cara dan sumber daya itu serta tanpa memberi tekanan yang tidak wajar terhadap pelaksanaannya." Menurut Sedarmayanti (2013: 82), "efektivitas merupakan tingkat keberhasilan organisasi dalam usaha untuk mencapai tujuan atau sasaran."

Sutrisno (2010: 125-126) mengemukakan lima dimensi untuk mengukur efektivitas program, yaitu pemahaman program, ketepatan sasaran, ketepatan waktu, tercapainya tujuan dan adanya perubahan nyata.

\section{Pemahaman Program}

Pemahaman terhadap program merupakan kemampuan anggota organisasi dan juga target terhadap program yang dilaksanakan. Pemahaman terhadap program dapat dikatakan penting karena dengan adanya pemahaman maka akan mengetahui apa yang harus dilakukan dalam pelaksanaannya. Dimensi ini digunakan untuk mengukur sejauhmana masyarakat memahami tentang program rehabilitasi korban perdagangan orang.

\section{Ketepatan Sasaran}

Ketepatan sasaran merupakan salah satu hal penting dalam menjalankan suatu program. Karena dengan tepatnya suatu sasaran maka akan memudahkan tujuan dari program dapat tercapai. Dimensi ini digunakan untuk mengukur apakah program yang dilaksanakan oleh Dinas Sosial Kota sukabumi sudah sesuai dengan kebutuhan masyarakat, apakah program yang dilaksanakan bermanfaat bagi yang menerima atau tidak. Dimensi ini penting digunakan untuk mengetahui efektivitas suatu program.

\section{Ketepatan Waktu}

Penggunaan waktu yang sesuai akan menjadikan tujuan dari program dapat dilaksanakan dengan baik sejalan dan sesuai dengan rencana yang telah dirumuskan sebelumnya. Dimensi ini dapat digunakan untuk mengetahui apakah program yang dilaksanakan sudah sesuai dengan waktu yang telah ditetapkan sebelumnya.

\section{Tercapainya Tujuan}

Tercapainya suatu tujuan merupakan tolak ukur suatu keberhasilan dalam suatu program. Dengan tercapainya suatu tujuan maka akan membuat program dikatakan efektif karena sudah sesuai dengan rencana. Tercapainya tujuan suatu program dapat dilihat dari terlaksana atau tercapainya misi dan tujuan program tersebut.

\section{Perubahan Nyata}

Adanya suatu perubahan nyata merupakan harapan dari terlaksananya suatu program. Dengan adanya atau timbulnya suatu perubahan nyata dari suatu program maka program tersebut dapat dikatakan berhasil dalam mencapai tujuannya karena menghasilkan suatu luaran (output) atau mendatangkan dampak (outcome) tertentu. Dimensi ini dapat digunakan untuk melihat perubahan kondisi mental-psikis dan sosial korban perdagangan orang sebelum dan sesudah mengikuti program rehabilitasi di Dinas Sosial Kota Sukabumi. 


\section{Metode}

Penelitian ini dilaksanakan pada Dinas Sosial Kota Sukabumi. Metode yang digunakan dalam penelitian ini adalah pendekatan kualitatif yang dipadukan dengan penelitian deskriptif untuk menggambarkan fenomena sebenarnya dari kejadian-kejadian di lapangan. Pengumpulan data penelitian menggunakan teknik wawancara, observasi dan dokumentasi yang terkait dengan penelitian.

Data primer dikumpulkan melalui wawancara dari informan penelitian. Informan penelitian ditentukan dari orangorang yang dianggap mengetahui dan memahami hal-hal terkait fokus penelitian sehingga mampu memberikan informasi yang diperlukan (Tabel 3).

Tabel 3. Informan Penelitian

\begin{tabular}{|c|c|c|}
\hline Informan & Jabatan & Alasan \\
\hline Informan 1 & $\begin{array}{l}\text { Kepala Dinas } \\
\text { Sosial Kota } \\
\text { Sukabumi }\end{array}$ & $\begin{array}{l}\text { Pengarah } \\
\text { program } \\
\text { rehabilitasi }\end{array}$ \\
\hline Informan 2 & $\begin{array}{l}\text { Kepala Bidang } \\
\text { Rehabilitasi } \\
\text { Sosial Dinas } \\
\text { Sosial Kota } \\
\text { Sukabumi }\end{array}$ & $\begin{array}{l}\text { Pelaksana } \\
\text { program } \\
\text { rehabilitasi }\end{array}$ \\
\hline Informan 3 & $\begin{array}{l}\text { Satuan Bakti } \\
\text { Pekerja Sosial } \\
\text { Dinas Sosial Kota } \\
\text { Sukabumi }\end{array}$ & $\begin{array}{l}\text { Pendamping } \\
\text { pelaksana } \\
\text { program } \\
\text { rehabilitasi }\end{array}$ \\
\hline Informan 4 & $\begin{array}{l}\text { Korban } \\
\text { Perdagangan } \\
\text { Orang }\end{array}$ & $\begin{array}{l}\text { Pihak yang } \\
\text { direhabilitasi }\end{array}$ \\
\hline Informan 5 & $\begin{array}{l}\text { Korban } \\
\text { Perdagangan } \\
\text { Orang }\end{array}$ & $\begin{array}{l}\text { Pihak yang } \\
\text { direhabilitasi }\end{array}$ \\
\hline
\end{tabular}

Penentuan informan penelitian menggunakan non probability sampling dengan metode snowball sampling, yaitu teknik pengambilan sampel yang semula jumlahnya kecil namun semakin lama jumlahnya akan bertambah sesuai dengan informasi yang dibutuhkan. Data penelitian dideskripsikan secara kualitatif dengan mengikuti tahapan mulai dari pengumpulan data, reduksi data, penyajian data hingga penarikan kesimpulan.

\section{HASIL DAN PEMBAHASAN}

\section{Pemahaman Program}

Pemahaman program harus dimiliki oleh pembuat program dan pelaksana program. Pembuat dan pelaksana juga harus mengetahui tujuan dari program yang dilaksanakan. Adapun tujuan dari program rehabilitasi korban perdagangan orang menurut Perda Kota Sukabumi Nomor 6 Tahun 2016 tentang Penyelenggaraan Kesejahteraan Sosial dalam Pasal 16, yaitu rehabilitasi sosial bertujuan untuk memulihkan dan mengembangkan kemampuan Penyandang Masalah Kesejahteraan Sosial (PMKS) yang mengalami disfungsi sosial agar dapat melaksanakan fungsi sosialnya secara wajar seperti mengembalikan keberfungsian secara fisik, mental, dan sosial, serta memberikan dan meningkatkan keterampilan.

Program rehabilitasi adalah salah satu program yang terdapat dalam Perda Kota Sukabumi Nomor 6 Tahun 2016 yang merupakan tindak lanjut atas UndangUndang Nomor 21 Tahun 2007 tentang Pemberantasan Tindak Pidana Perdagangan Orang. Pasal 51 mengatur bahwa korban berhak memperoleh rehabilitasi kesehatan, rehabilitasi sosial, dan reintegrasi sosial dari pemerintah apabila yang bersangkutan mengalami penderitaan baik secara fisik maupun psikis akibat tindak pidana perdagangan orang.

Tujuan dari program rehabilitasi perdagangan orang sesuai dengan semestinya namun dalam pelaksanaannya terdapat hambatan berupa kurangnya fasilitas ruangan untuk proses pelaksanaan rehabilitasi. Kurangnya fasilitas ruangan atau tempat ini tidak sesuai dengan Perda Kota Sukabumi Nomor 6 Tahun 2016 tentang Penyelenggaraan Kesejahteraan Sosial, dimana Pasal 11 mengatur tentang pemenuhan sarana dan prasarana penyelenggaraan kesejahteraan sosial yang meliputi pusat kesejahteraan sosial, rumah singgah dan rumah perlindungan sosial. Adanya suatu tempat seperti yang sudah dikatakan 
di atas diharapkan mampu memaksimalkan proses rehabilitasi, namun dalam pelaksanaannya tidak berjalan dengan semestinya.

Berdasarkan hasil wawancara dengan informan penelitian dapat diketahui bahwa landasan dari program rehabilitasi korban perdagangan orang adalah Perda Kota Sukabumi Nomor 6 Tahun 2016 yang dilaksanakan oleh Dinas Sosial Kota Sukabumi sebagai unsur pelaksana pemerintah daerah dalam bidang sosial. Namun hasil wawancara dengan informan yang menjadi korban perdagangan orang dan yang mengikuti program rehabilitasi belum mengetahui tentang landasan program tersebut. Landasan tersebut diketahuinya pada saat mengikuti rehabilitasi.

Dari hasil wawancara peneliti dengan informan dapat diinterpretasikan bahwa pelaksana program yaitu Dinas Sosial Kota Sukabumi memahami program yang dijalankan berdasarkan landasan hukum yang berlaku. Namun dari segi masyarakat yang mengikuti program belum memahami terkait landasan dari program yang diikutinya. Informan tersebut mengetahui tentang landasan tersebut pada saat setelah menjalani rehabilitasi.

Korban perdagangan orang ataupun masyarakat biasa belum semua mengetahui terkait landasan hukum dan juga program rehabilitasi, maka peneliti bertanya kepada informan mengenai bagaimana alur jika seseorang merupakan korban perdagangan dan memerlukan rehabilitasi. Jawaban informan menggambarkan bahwa selaku pelaksana program dalam kasus perdagangan orang, Dinas Sosial Kota Sukabumi berkoordinasi dengan Pusat Pelayanan Terpadu Pemberdayaan Perempuan dan Anak (P2TP2A) karena sebagian besar korban perdagangan orang merupakan perempuan.

Alur penanganan korban perdagangan orang dengan alur penanganan perempuan dan anak korban kekerasan anak merupakan alur yang sama. Penanganan perdagangan orang menempuh tiga alur, yaitu (1) datang sendiri yang merupakan melapor kepada dinas yang berwenang bahwa dirinya merupakan korban dari perdagangan orang untuk dapat ditindak lanjuti dan juga meminta perlindungan. Lalu (2) ada pula rujukan dari lingkungan yang mengetahui terdapat korban di lingkungan sekitarnya. Lalu yang terakhir adalah (3) penjangkauan yang merupakan proses menganalisis tempat-tempat yang memiliki risiko terjadinya kasus perdagangan orang.

Peneliti juga bertanya kepada informan terkait alur penanganan kepada korban yang memang sudah merasakan bagaimana alur ini berjalan. Informan menyatakan bahwa proses penanganan dari awal sampai rehabilitasi, yaitu bermula saat hasil dari penjangkauan dari dinas setempat, lalu diberitahukan kepada Dinas Sosial Kota Sukabumi, lalu dijemput oleh pihak Dinas untuk didata dan langsung dipulangkan.

Sesuai yang dikatakan oleh informan bahwa korban perdagangan orang yang merupakan warga Kota Sukabumi namun ditemukan diluar Kota Sukabumi akan dijemput oleh pihak Dinas Sosial menggunakan mobil operasional ke tempat korban tersebut berada sesuai dengan pemberitahuan terlebih dahulu kepada pihak Dinas. Hasil wawancara peneliti dengan informan menunjukkan bahwa setelah berada di Dinas Sosial Kota Sukabumi informan hanya dimintai data lalu dipulangkan ke rumah tanpa adanya proses yang seharusnya dilakukan seperti dalam alur penanganan.

Peneliti menginterpretasikan bahwa dari hasil wawancara dengan beberapa informan dapat diketahui bahwa dalam pelaksanaan program rehabilitasi ini terdapat alur pertama yang akan membawa korban untuk dapat mengikuti program rehabilitasi. Dalam keseluruhan penelitian mengenai dimensi pemahaman program ini peneliti berpendapat bahwa mengukur efektivitas program rehabilitasi dengan melihat pemahaman program dari pihak pelaksana sudah baik namun dari pihak 
yang mengikuti program belum sepenuhnya mengerti.

Selain itu, jika dilihat dari alur penanganan pihak Dinas Sosial sudah berusaha maksimal dalam menjalankan tugasnya seperti menjemput korban di luar kota untuk dapat ditindaklanjuti di Dinas Sosial Kota Sukabumi, namun pada saat proses penindaklanjutan tersebut tidak secara keseluruhan dilaksanakan seperti yang sudah dikatakan oleh informan. Jika melihat pedoman alur penanganan, seharusnya pihak pelaksana yang memiliki wewenang melakukan cek kesehatan, melakukan konseling awal, dan yang tahap selanjutnya yaitu rehabilitasi untuk memulihkannya.

\section{Ketepatan Sasaran}

Dalam hal ini tepat sasaran diartikan bahwa program rehabilitasi sesuai dengan kebutuhan korban Perdagangan Orang. Tepat sasaran merupakan salah satu hal penting dalam menjalankan suatu program. Karena dengan tepatnya suatu sasaran maka akan memudahkan tujuan dari program dapat tercapai.

Langkah-langkah yang dilakukan untuk mencapainya tujuan dari rehabilitasi yaitu persuasif seperti bujukan yang bertujuan untuk memberi keyakinan agar seseorang bersedia direhabilitasi sosial. Lalu motivasi pemberian semangat kepada korban, dan yang terakhir yaitu koersif tindakan pemaksaan terhadap seseorang dalam proses rehabilitasi sosial yang dilakukan di Dinas Sosial. Namun langkah langkah tersebut belum maksimal dilaksanakan oleh Dinas Sosial karena korban yang direhabilitasi masih merasa kurang terbantu secara keseluruhan dalam pemulihan fisik ini.

Selain itu metode koersif atau paksaan belum sepenuhnya berjalan di dalam program ini karena tidak semua korban perdagangan orang dipaksakan untuk mengikuti rehabilitasi, jika memang korban tidak mau maka pihak pelaksanapun akan membiarkan korban tersebut untuk pulang ke keluarganya. Hal ini terjadi karena kurang terkoordinirnya metode persuasif, motivasi dan koersif yang sesuai dengan Perda Kota Sukabumi Nomor 6 Tahun 2016. Suatu program dibuat lalu dilaksanakan terdapat tujuan dan harapan di dalamnya. Adapun tujuan dari terlaksanakannya program rehabilitasi adalah agar dapat memulihkan kondisi fisik dan psikis korban yang mengalami trauma agar dapat kembali menjalankan fungsi sosialnya dan hidup wajar seperti sebelumnya.

Dalam dimensi ini, peneliti menganalisis terkait sejauhmana program rehabilitasi dapat mengenai sasarannya. Hal tersebut peneliti lakukan dengan mencari tahu tentang kriteria korban yang dapat direhabilitasi. Peneliti menanyakan kepada informan mengenai kriteria korban yang berhak mendapatkan rehabilitasi. Apa yang telah disampaikan oleh informan terkait kriteria korban perdagangan orang yang dapat direhabilitasi pada intinya sesuai dengan Peraturan Menteri Sosial Republik Indonesia Nomor 8 Tahun 2012, yaitu orang-orang yang mengalami eksploitasi seksual, mengalami tindakan kekerasan dan juga mengalami penelantaran. Sehingga orang-orang dengan kriterai tersebut dapat mengikuti rehabilitasi sosial. Rehabilitasi sosial dasar yang dilaksanakan di luar panti sosial mampu dilaksanakan sesuai rujukan, yaitu kepada keluarga, panti sosial, balai besar, balai loka. Rehabilitasi sosial dasar di dalam panti sosial dilaksanakan oleh unit pelaksana teknis milik pemerintah daerah provinsi dan Lembaga Kesejahteraan Sosial (LKS) yang ditetapkan oleh gubernur.

Pelaksanaan rehabilitasi di Dinas Sosial Kota Sukabumi, khususnya perdagangan orang merupakan rehabilitasi dasar. Rehabilitasi dasar menurut Peraturan Menteri Sosial Nomor 16 Tahun 2019 tentang Standar Nasional Rehabilitasi Sosial menyebutkan bahwa rehabilitasi dasar yaitu upaya yang dilakukan untuk memulihkan fungsi sosial seseorang. Sehingga pihak pelaksana yaitu Dinas Sosial Kota Sukabumi melakukan rehabilitasi dasar korban perdagangan orang dengan tetap menempatkan- 
nya bersama keluarga, namun dengan pemantauan dan juga pemberian edukasi dan motivasi dari pihak pelaksana. Sedangkan jika rehabilitasi lanjutan yang sesuai dengan Peraturan Menteri Sosial No 16 Tahun 2019, maka dalam Pasal 26 dilakukan upaya untuk mengembangkan fungsi sosial individu, keluarga, kelompok dan masyarakat. Dalam pelaksanaannya, rehabilitasi lanjut dapat berbentuk motivasi, pengasuhan, pelatihan vokasional dan pembinaan kewirausahaan, bimbingan resosialisasi, rujukan dan juga dapat berbentuk terapi fisik, mental spiritual dan terapi psikososial. Terapi tersebut dilaksanakan oleh pekerja sosial yang bekerja sama dengan tenaga profesional.

Proses rehabilitasi yang dilaksanakan di rumah masing-masing menunjukkan adanya keterbatasan fasilitas yang dimiliki. Dinas Sosial Kota Sukabumi memiliki rumah singgah untuk tempat rehabilitasi semua jenis PMKS namun masih dalam tahap pembangunan. Pemerintah Kota Sukabumi memiliki rumah singgah di Bandung untuk warga Kota Sukabumi yang membutuhkan perawatan di Bandung namun memiliki keterbatasan ekonomi. Sehingga jika ada korban yang membutuhkan rehabilitasi lanjutan maka akan dikirimkan ke panti-panti sosial baik yang dikelola oleh pemerintah maupun mandiri.

Dapat diinterpretasikan dari hasil wawancara dengan informan bahwa dari aspek sarana untuk tempat rehabilitasi pihak, Pemerintah Kota Sukabumi sudah memiliki namun bertempat di Bandung dan jika di wilayah Kota Sukabumi sendiri seperti yang sudah diungkapkan informan bahwa tempat rehabilitasi tersebut sedang dibangun. Hal itu disebabkan karena proses rehabilitasi yang dilaksanakan merupakan rehabilitasi dasar yang dilakukan di rumah korban masing-masing. Hal tersebut membuat proses rehabilitasi kurang berjalan dengan semestinya karena ada korban yang merupakan peserta rehabilitasi namun tidak ada tindakan dari pihak pelaksana sebagaimana dikatakan informan.

\section{Ketepatan Waktu}

Penggunaan waktu yang sesuai akan membuat tujuan dari program dapat terlaksana dengan baik sesuai dengan rencana. Proses rehabilitasi bagi korban perdagangan orang dengan tanggap direhabilitasi oleh Dinas Sosial Kota Sukabumi. Namun dalam hal ini tidak semua korban perdagangan orang direhabilitasi, karena apabila korban tersebut ingin langsung kembali kepada keluarganya, pihak Dinas Sosial Kota Sukabumi tidak bisa memaksa untuk dilakukan rehabilitasi. Dalam dimensi tepat waktu mengenai jangka waktu atau kesesuaian waktu dalam pelaksanaan rehabilitasi korban perdagangan orang oleh Dinas Sosial Kota Sukabumi dengan memperhatikan apakah korban yang sudah ditemukan itu langsung direhabilitasi atau tidak dan apakah ada jangka waktu dalam proses rehabilitasi korban perdagangan orang.

Seperti yang dikatakan oleh informan bahwa rehabilitasi yang dilaksanakan kepada korban perdagangan orang itu merupakan rehabilitasi dasar yang dilakukan bersama keluarganya di rumah, maka karena dilaksanakan di rumah membuat tidak ada jangka waktu dalam pelaksanaannya. Terlihat bagaimana progres dalam rehabilitasi. Jika sudah membaik dari berbagai aspek, maka akan dikatakan selesai.

Informan juga menyatakan bahwa tidak ada jangka waktu atau batas waktu terkait pelaksanaan rehabilitasi. Rehabilitasi dilaksanakan sesuai dengan kebutuhan korban. Sedangkan jika rehabilitasi dasar dilaksanakan di dalam panti sosial maka akan dilaksanakan paling singkat selama 3 bulan yang selanjutnya akan ditinjau kembali apakah akan dipulangkan atau mendapatkan rehabilitasi lanjutan.

\section{Tercapainya Tujuan}

Pelaksanaan suatu program tentunya memiliki tujuan yang akan dicapai, karena tercapainya suatu tujuan akan berpengaruh terhadap efektivitas program tersebut. Dalam pelaksanaan program, lembaga atau 
organisasi harus merencanakan tujuan yang akan dicapai agar program tersebut berjalan dengan terarah. Dalam proses rehabilitasi ini terdapat kekurangan yang membuat belum maksimalnya tujuan tercapai. Terdapat beberapa hambatan yang terjadi dalam program ini seperti kurang mengimplementasikan langkahlangkah dalam rehabilitasi seperti persuasif, motivasi dan koersif. Selain itu, kurangnya anggaran yang didapatkan Dinas Sosial Kota Sukabumi. Anggaran yang didapatkan Dinas Sosial Kota Sukabumi merupakan anggaran yang diberikan dari Anggaran Pendapatan dan Belanja Negara, Anggaran Pendapatan dan Belanja Daerah Provinsi, Anggaran Pendapatan dan Belanja Daerah, dan sumbangan masyarakat.

Pencapaian program menjadi tolok ukur untuk dapat menilai suatu program apakah berjalan dengan baik. Dalam pencapaian program perlu diperhatikan beberapa hal seperti langkah yang akan diambil untuk mencapai tujuan tersebut dan juga hambatannya. Sehingga dapat diperbaiki, jika tidak maka akan timbul masalah untuk merealisasikan tujuan program. Begitu pula yang terjadi di Dinas Sosial yang sudah berusaha menjalankan program dengan baik namun masih ada kekurangannya seperti kurang terorganisirnya kegiatankegiatan selama korban direhabilitasi dan juga kurangnya anggaran yang ada sehingga membuat tidak semua korban rehabilitasi merasakan dampak yang maksimal dari program tersebut.

Hasil wawancara dengan informan terkait tercapainya tujuan dapat diinterpretasikan bahwa tujuan dari program ini sudah sesuai dengan semestinya namun masih terdapat hambatan, yaitu kurangnya fasilitas ruangan untuk proses pelaksanaan rehabilitasi. Kurangnya fasilitas ruangan atau tempat ini tidak sesuai dengan Perda Kota Sukabumi Nomor 6 Tahun 2016 tentang Penyelenggaraan Kesejahteraan Sosial, dimana Pasal 11 mengatur tentang tentang Sarana dan prasarana penyelenggaraan kesejahteraan sosial yang meliputi pusat kesejahteraan sosial, rumah singgah, rumah perlindungan sosial. Adanya suatu sarana dan prasarana yang memadai seperti yang sudah dikatakan di atas diharapkan mampu memaksimalkan proses rehabilitasi, namun dalam pelaksanaannya tidak berjalan dengan semestinya. Sehubungan dengan kurangnya sarana dan prasarana dalam proses rehabilitasi maka peneliti menanyakan kembali kepada informan terkait apa saja yang dilakukan oleh pihak pelaksana untuk mencapainya tujuan dari program rehabilitasi.

\section{Adanya Perubahan Nyata}

Adanya suatu perubahan nyata merupakan harapan dari terlaksananya suatu program. Dengan adanya suatu perubahan nyata dari suatu program maka program tersebut dapat dikatakan berhasil dalam mencapai tujuannya karena menghasilkan suatu luaran (output) atau mendatangkan dampak (outcome) yang nyata.

Adanya rehabilitasi tentu dimaksudkan untuk memperbaiki berbagai aspek seperti mental, iman, dan kesiapan untuk kembali ke keluarga dan agar para korban penjualan orang tidak merasakan hal yang serupa. Namun dalam program rehabilitasi ini terdapat beberapa kekurangan seperti persepsi korban perdagangan orang mengenai rehabilitasi sangat ditakuti. Selain itu, pada saat proses rehabilitasi ini tidak banyak kegiatan yang dilakukan sehingga kurang maksimalnya output dan outcome yang dirasakan oleh korban perdagangan orang yang telah direhabilitasi.

Hasil wawancara terkait adanya perubahan nyata dari rehabilitasi dapat peneliti interpretasikan bahwa Dinas Sosial selaku pelaksana sudah berusaha semaksimal mungkin dalam menjalankan salah satu tugasnya, yaitu program rehabilitasi, namun jika dilihat dari jawaban informan yang menjadi korban dan mengikuti program tersebut bahwa program rehabilitasi ini berjalan dengan kurang jelasnya kegiatan dan arahan yang ada sehingga 
membuat korban belum merasakan dampak maksimak dari rehabilitasi.

\section{KESIMPULAN DAN REKOMENDASI}

\section{Kesimpulan}

Efektivitas pelaksanaan program rehabilitasi korban perdagangan orang di Kota Sukabumi secara umum dinilai baik, meskipun terdapat beberapa hambatan yang terjadi pada pelaksanaannya seperti kurangnya fasilitas ruangan atau tempat rehabilitasi. Hal ini tidak sesuai dengan Peraturan Daerah Kota Sukabumi Nomor 6 Tahun 2016 tentang Penyelenggaraan Kesejahteraan Sosial, Pasal 11, yang mengatur tentang sarana dan prasarana penyelenggaraan kesejahteraan sosial seperti pusat kesejahteraan sosial, rumah singgah, rumah perlindungan sosial, kurang terkoordinirnya metode persuasif, motivasi dan koersif.

Tidak semua korban perdagangan orang direhabilitasi, kurang terorganisirnya kegiatan-kegiatan selama korban direhabilitasi dan juga kurangnya anggaran yang tersedia sehingga membuat tidak semua korban rehabilitasi merasakan dampak yang maksimal dari program tersebut, persepsi korban perdagangan orang mengenai rehabilitasi sangat ditakuti. Selain itu pada saat proses rehabilitasi tidak banyak kegiatan yang dilakukan sehingga kurang maksimalnya hasil yang dirasakan oleh korban perdagangan orang yang telah direhabilitasi.

\section{Rekomendasi}

Berdasarkan kesimpulan tersebut, peneliti merekomendasikan hal-hal sebagai berikut:

1. Pemerintah Kota Sukabumi diharapkan memperhatikan dan menyediakan fasilitas bagi peserta rehabilitasi sehingga mampu memaksimalkan proses rehabilitasi.

2. Pelaksana program rehabilitasi diharapkan mempunyai kemampuan reha- bilitasi sosial dengan metode persuasif, motivasi dan koersif sehingga korban tersebut bersedia secara sukarela untuk direhabilitasi.

3. Korban perdagangan orang sebaiknya diwajibkan untuk mengikuti proses rehabilitasi mengingat perdagangan orang memiliki dampak yang besar bagi korban seperti trauma karena kejadian yang dialami sangat membuatnya takut.

4. Pelaksana program rehabilitasi diharapkan dengan sungguh-sungguh dapat menjalankan programnya, dan Pemerintah Kota Sukabumi diharapkan dapat mengalokasikan anggaran untuk pelaksanaan program rehabilitasi korban perdagangan orang.

5. Pelaksana program rehabilitasi diharapkan melakukan sosialisasi kepada seluruh elemen masyarakat sehingga tidak menimbulkan persepsi masyarakat yang takut akan rehabilitasi korban perdagangan orang.

\section{DAFTAR PUSTAKA}

\section{Buku}

Badrudin. (2013). Dasar-dasar Manajemen. Bandung: Alfabeta.

Sedarmayanti. (2013). Reformasi Administrasi Publik, Reformasi Birokrasi, dan Kepemimpinan Masa Depan. Bandung: Refika Aditama.

Steers, Richard M. (1985). Efektivitas Organisasi. Jakarta: Erlangga.

Sutrisno, Edy. (2010). Manajemen Sumber Daya Manusia. Jakarta: Kencana.

\section{Dokumen}

Dinas Sosial Kota Sukabumi. (2019). Data Perdagangan Orang di Kota Sukabumi. Sukabumi: Dinas Sosial Kota Sukabumi.

Dinas Sosial Kota Sukabumi. (2019). Data Rehabilitasi Korban Perdagangan Orang di Kota Sukabumi. Sukabumi: Dinas Sosial Kota Sukabumi. 


\section{Peraturan Perundang-undangan}

Peraturan Daerah Kota Sukabumi Nomor 6 Tahun 2016 tentang Penyelenggaraan Kesejahteraan Sosial (Lembaran Daerah Kota Sukabumi Tahun 2016 Nomor 6).

Peraturan Menteri Sosial Nomor 8 Tahun 2012 tentang Pedoman Pendataan dan Pengelolaan Data Penyandang Masalah Kesejahteraan Sosial dan Potensi dan Sumber Kesejahteraan Sosial (Berita Negara Republik Indonesia Tahun 2012 Nomor 567).

Peraturan Menteri Sosial Nomor 16 Tahun 2019 tentang Standar Nasional Rehabilitasi Sosial (Berita Negara Republik Indonesia Tahun 2019 Nomor 1306).

Undang-Undang Nomor 21 Tahun 2007 tentang Pemberantasan Tindak Pidana Perdagangan Orang (Lembaran Negara Republik Indonesia Tahun 2007 Nomor 58, Tambahan Lembaran Negara Republik Indonesia Nomor 4720).

\section{Laman}

Catatan International Organization for Migration (IOM): Human Trafficking Paling Banyak Terjadi di Indonesia. https://www.liputan6.com/news/ $\mathrm{read} / 2249883$ /catatan-iom-humantrafficking-paling-banyak-terjadi-diindonesia/, diakses tanggal 18 Januari 2020. 